\title{
PREPARING FUTURE HANDICRAFT TEACHERS FOR INCLUSIVE EDUCATION IN UKRAINIAN SCHOOLS
}

\author{
IRYNA ANDROSHCHUK, IHOR ANDROSHCHUK, HANNA KRASYLNYKOVA
}

\begin{abstract}
The paper highlights the results of empirical research regarding the issues undermining the implementation of inclusive education in the context of training handicraft teachers and, consequently, discovers effective ways to eliminate them. It shows that future handicraft teachers are mostly not ready to implement inclusive education. This is due to the lack of adequate knowledge and skills required to work with children with special needs. Besides, the paper indicates students' unawareness of categories of children with special needs and characteristics of correctional and developmental work in handicraft lessons, including relevant exercises, motor activity. This fact negatively affects future teachers' emotional readiness to work under such conditions. Working with various tools while processing structural materials requires adherence to safety rules in lessons and appropriate organization of design and technological activities. The paper specifies that teacher placement supervisors do not have the necessary experience of working with children with special needs and thus cannot prepare their students for that. Also, it justifies the need to develop students' emotional readiness to work with children with special needs, update the content of professional training for future handicraft teachers, taking into account the specifics of inclusive education, develop their ability to employ teaching methods appropriate for inclusive classes in handicraft lessons. Finally, the paper isolates the main areas that can help to increase the effectiveness of professional training of future handicraft teachers in higher education institutions so that they can work with children with special needs.
\end{abstract}

Keywords: handicraft teachers, inclusive education, children with special needs.

\section{INTRODUCTION}

The need to create inclusive educational space in Ukraine has been on the agenda since the declaration of its independence in 1991. It can be explained by the fact that today the number of people with special needs increased by 3 million people (6\%), including 165 thousand children, which is twice as much as in 1990 (3\%). The main problem for this category of the population lies in the unequal access to all benefits of modern civilization and, primarily, education. However, only 1127 Ukrainian schools (6.5\% of the total number) introduce the principles of inclusion in the educational process. In comparison: this figure reaches $25 \%$ in France, $42 \%$ - in Poland and Slovakia, 57\% - in Hungary, 90\% in Norway and Lithuania, 99\% - in Italy [4].

The legal realization of the right to education for all children was settled in 2017 with the adoption of relevant Laws of Ukraine, in particular, the Law of Ukraine "On Education" [11]. This law recognizes that inclusive education is a system of educational services guaranteed by the state and is based on the 
principles of non-discrimination, human diversity, active involvement and inclusion of all its participants in the educational process.

Today, the legal field of inclusive education in Ukraine is based on the Law of Ukraine as of May 23, 2017, No 2053-VIII “On Amendments to the Law of Ukraine "On Education" regarding the Access of Persons with Special Educational Needs to Educational Services", the Decrees of the Cabinet of Ministers of Ukraine as of August 9, 2017, No 558 "On Amendments to the Procedure for Organization of Inclusive Education in General Education Institutions" and as of July 12, 2017, No 545 "On Approval of the Provision on Inclusion Resource Center", the Order of the Cabinet of Ministers of Ukraine as of August 9, 2017, No 526-r "On the National Strategy for Reforming Institutional Care and Education of Children for 2017-2026 and the Plan of Stage 1 Implementation".

Clearly, the above-mentioned legal documents are based on international documents on inclusive education for persons with special needs, mainly designed by the United Nations. The critical document among them is the UN Convention on the Rights of the Child (UNCRC) (Unicef, 1989), which recognized the right of all children to education, including children with special needs [16]. It was between 1981 and 1992 that the European Community formulated the basic principles of inclusive education for children with special needs. The main principle was agreed to be the principle of involving children with special needs in the educational process through creating "a school for all", that is institutions, which unite everyone, take into account differences, facilitate the process of learning and meet the individual needs of children [6].

Concerning Ukraine, one can establish that the country aims towards the European model of inclusive education, even with a long delay, as evidenced by 8212 newly established inclusive classes in 2018 that is $40 \%$ more than in 2017. According to government officials, "from now on, all new schools in the country will be equipped with the inclusive educational environment" [5].

The need to create the European Higher Education Area, where higher education can effectively help to build an inclusive society based on democratic values and human rights, was discussed at the 2015 Yerevan Ministerial Conference. Subsequently, the plan of action until 2020 was approved [3]. The situation with an inclusive environment in Ukrainian higher education is still rather complicated. As evidenced by the data provided by the Ministry of Education and Science of Ukraine, more than $4 \%$ of Ukrainian students (10 thousand out of the total number of 2.5 million) are students with special needs. Most of them study in state higher education institutions (55\%) [8]. It must be noted, however, that there are no state programmes for supporting young people with special needs in obtaining higher education.

In Ukraine, therefore, future teachers do not acquire the competencies required to implement inclusive education, do not gain the necessary knowledge of the inclusive educational environment. Particularly relevant is the problem related to the acquisition of particular competencies in working with children with special needs by handicraft teachers since they involve pupils in various types of educational and physical activities, familiarize them with elements of manual work, including processing various materials and design, different kinds of sports, which can surely be used as a means of rehabilitation for children with special needs.

The value of manual work for children with special needs increases due to the need to develop their skills in a chosen occupational area (acquiring practical skills, developing an interest in social selfdetermination, self-adaptation), which will help them to obtain vocational or higher education and receive employment opportunities.

\section{THEORETICAL BACKGROUND}

European integration processes in the early 2000s led to the emergence of new cultural and educational norms in Ukraine, such as respect for people with physical and mental disorders and enforcement of the right to quality education for children with special educational needs. The legal basis for such changes incorporates the adoption of the Law of Ukraine "On Ratification of the Convention on the Rights of Persons with Disabilities and Optional Protocol to It" [12], the Resolution 
of the Cabinet of Ministers of Ukraine "On Approval of Arrangement Procedure of Inclusive Education in Secondary Schools" [9] and the Concept of Inclusive Education Development [10].

It is at this time that Ukrainian researchers start addressing the following issues of inclusion: the social value of the individual in the context of humanistic pedagogy (S. Amonashvili, A. Maslow, K. Rogers. M. Suprun); teachers' readiness for pedagogically correctional work in the context of professional pedagogy (A. Bykov, I. Bekh, V. Bondar, S. Boltivets, H. Bondarenko, T. Danylova, N. Dementieva, T. Iliashenko, A. Kihichak, O. Khokhlina, A. Panov, T. Shulha); theories and practices of inclusive education for persons with psychophysical disorders (V. Bondar, L. Budiak, I. Dmytriieva, A. Kolupaieva, S. Myronova, T. Sak, M. Sheremet, V. Synov, V. Zasenko). The issues of inclusion of people with special needs in society are mainly considered in the following aspects: medical and social (O. Chaban, I. Katkova, V. Kuznietsov, S. Sarycheva); socio-psychological (O. Asmolov, I. Rasiuk, M. Semaho, O. Usanova); socio-pedagogical (M. Chaikovskyi, O. Dikova-Favorska, S. Inozemtseva, E. Isaieva, I. Kuzava, I. Makarenko, V. Skrypnyk, T. Soloviova, A. Tamm, O. Vasylenko); pedagogical (S. Andriichuk, N. Diatlenko, B. Hershunskyi, N. Sofii, M. Voitsekhivskyi, I. Ziaziun, V. Zhuravskyi). Some scholars (V. Kovalenko, O. Postupna, N. Teplova, T. Yartseva, Yu. Zhuravlova) disclose the ways of reforming mechanisms of state regulation of Ukrainian education, including through the implementation of an inclusive approach.

It was during the All-Ukrainian scientific-pedagogical experiment "Social Adaptation and Inclusion of Children with Psychophysical Disorders in Society through the Arrangement of Their Education in Secondary Schools" (2001-2007) when one first addressed the issue of training secondary schools teachers to work with children with special needs with the help of skills development workshops and advanced training courses. A 72-hour course was specially developed within the framework of the experiment. It aimed to acquaint secondary school teachers with the peculiarities of such children's development, forms and methods of working with them, as well as the content of correctional and rehabilitation work.

Since 2019, the All-Ukrainian Foundation "Step by Step" has been implementing several projects aimed at creating a professional standard for new generation teachers and training of teacher assistants (nursery teachers and teachers). Indeed, they should be able to work in an inclusive educational environment, namely, an environment where children with special educational needs can learn. Canadian colleges offer effective programmes for assistant teachers (10-36 months) which prepare them for work with such children, as well as distance learning courses in postgraduate education. Importantly, college and university teachers themselves have practical experience in inclusive education.

In Ukraine, relevant specialists have developed a textbook, titled "Professional Activities of Teacher Assistants in an Inclusive Classroom" [15]. It is recommended for both teacher assistants from secondary schools and lecturers from graduate teacher training institutions, who teach courses on inclusive education. However, Ukrainian pedagogical theory still lacks studies on professional training of teacher assistants and secondary school teachers who work with children with special educational needs. It is essential to promote research on the training of subject teachers from primary and secondary schools, including handicraft teachers, for professional activities in inclusive education.

\section{Research ObJective, Methodology and Data}

The object of research is the readiness handicraft teachers to implement inclusive education, as well as the issues decreasing their readiness.

The current research aims to identify the issues undermining the implementation of inclusive education in the context of training handicraft teachers and, consequently, to discover effective ways to eliminate them.

The following research methods were used:

- theoretical methods: a logical analysis of scientific researches; systemic analysis aimed at studying the problems of working with children with special needs in handicraft lessons; induction, 
deduction, synthesis and generalization aimed at justifying research findings and conclusions; generalization aimed at formulating conclusions and recommendations for training future handicraft teachers to work with children with special needs;

- empirical methods: archival research (study and analysis of teaching experience, curricula, training programmes for future handicraft teachers); survey and diagnostic methods (questionnaires, conversations, tests, interviews) aimed at identifying the factors and the capacity of training future handicraft teachers for pedagogical interaction;

- methods of quantitive and qualitative analysis and mathematical statistics aimed at processing and presenting research findings graphically.

The research sample comprised 300 respondents, including 57 handicraft teachers from general education institutions and 243 students majoring in secondary education (handicraft and technology)..

\section{RESULTS AND DisCUSSION}

As evidenced by the results of the study involving handicraft teachers conducted in between 2018 and 2019, there is an ambiguous attitude towards the introduction of inclusive education (see Fig. 1).

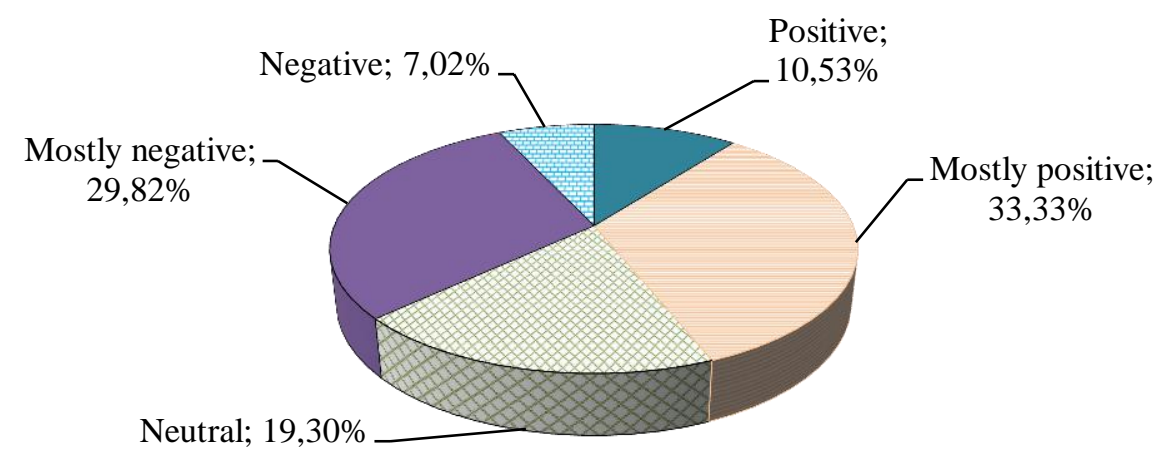

Fig. 1. An attitude of handicraft teachers towards inclusive education

Thus, only $10.53 \%$ of teachers have a positive attitude towards inclusive education and $33.33 \%$ - a mostly positive attitude. It is worrying that $7.02 \%$ of teachers have a negative attitude and $29.82 \%-a$ mostly negative attitude.

It must be noted that the vast majority of the respondents $(64.91 \%)$ do not know all the categories of children with special needs and therefore, are not ready to work with them. After the teachers were familiarized with all categories of children with special needs, they were asked to choose two or three categories with which they would be ready to work after preliminary training. The percentage distribution of handicraft teachers about their readiness to work with children with special needs is shown in Fig. 2. 


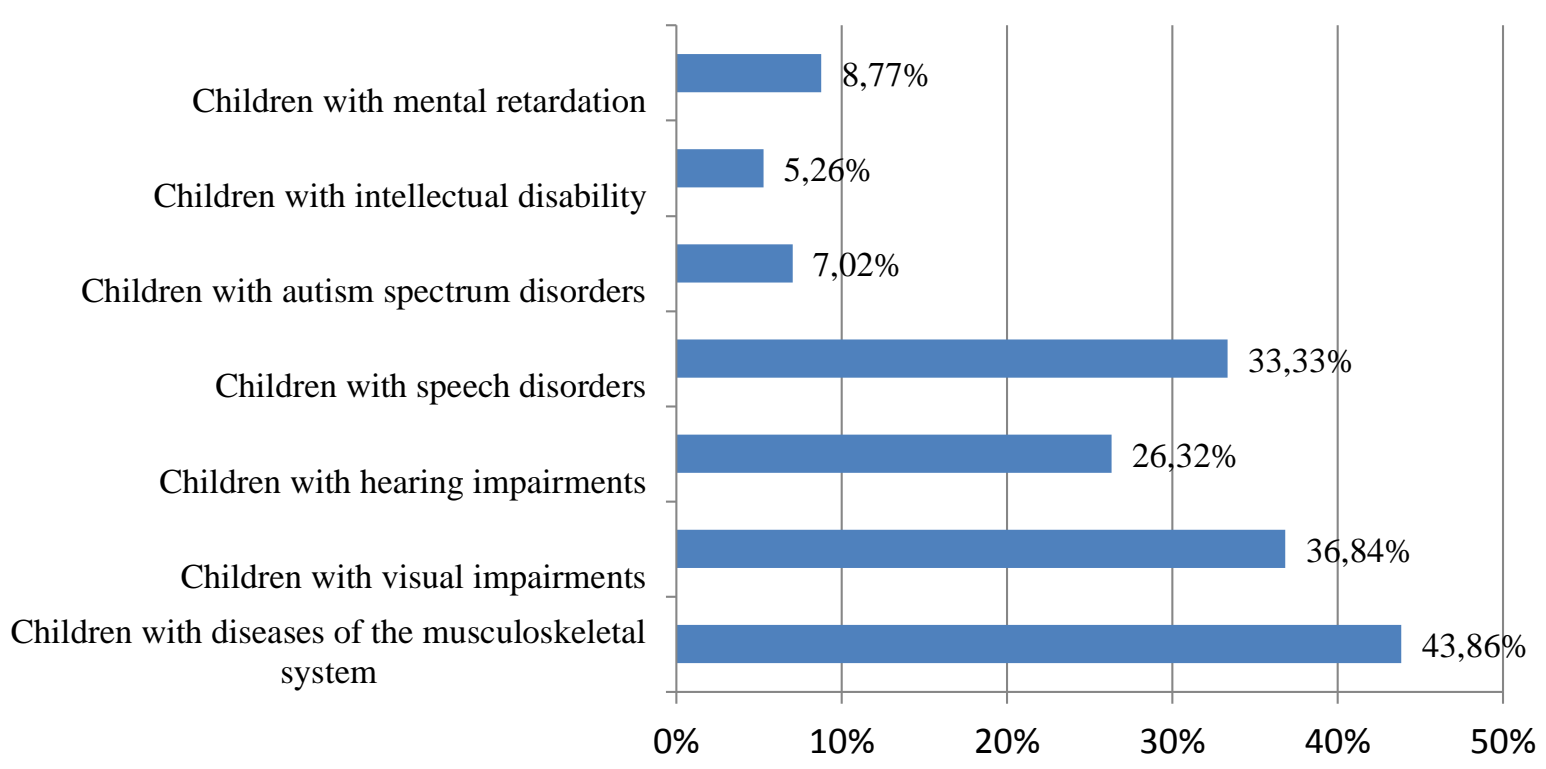

Fig. 2. Percentage distribution of handicraft teachers concerning their readiness to work with children with special needs.

Besides, the important role, along with the established system of professional-pedagogical knowledge and skills required to work with children with special needs, is played by the teacher's personality traits. Handicraft teachers consider the following personality traits to be the most relevant ones: love for children $(94.77 \%)$, tact $(77.19 \%)$, patience $(71.93 \%)$, kindness $(68.42 \%)$, sympathy $(64.91 \%)$, empathy $(56.14 \%)$, adequacy $(49.12 \%)$, optimism $(47.37 \%)$, organization $(40.35 \%)$, observation $(31.57 \%)$, etc.

Those teachers who work with children with special needs should have the following professional skills: the ability to employ an individual approach (92.98\%); the ability to choose the most optimal teaching forms and methods taking into account the category of disorders (80.7\%); the ability to overcome difficulties and find quick solutions to difficult situations $(77.19 \%)$; the ability to interact with other participants in the educational process $(63.16 \%)$.

In general, psychological readiness of teachers is the basis for working with children with special needs. To this end, it is of primary importance to approve the applicants who are able to work in the "man-man" system already at the stage of career guidance. Secondly, it is vital to hold training sessions, business games simulating pedagogical situations with children with special needs during professional training in higher education institutions so that future teachers can develop behavioural algorithms in most typical situations.

Indeed, it is hugely worrying that students do not possess the necessary knowledge of working with different categories of children with special needs. First of all, this is related to the specificity of handicraft lessons, active involvement of pupils in various exercises (manual or physical), motor activity, in particular during design and technological activities, which involve making a product or during sports games. It is precisely the activities with various tools when processing structural materials, which urge to adhere to safety guidelines and accurately organize the practical activity of pupils in the classroom. The processes of performing physical exercises and using sports equipment also require that specific rules and requirements should be followed to prevent injuries. It, in turn, causes the need to develop the following knowledge in future handicraft teachers: patterns and principles of inclusive education; categories of children with special needs, their psychological characteristics; forms and methods of inclusive education and handicrafts training; the interaction between the teacher and parents in the context of correctional and developmental work with children with special needs Taking into account foreign studies by some scholars $[1,7,13,14]$, it is expedient to update professional courses for future teachers, by supplementing them with relevant topics (see Table 1), which might help develop a system of relevant professional pedagogical knowledge. 


\begin{tabular}{|c|l|}
\hline Course & \multicolumn{1}{|c|}{ Topics } \\
\hline $\begin{array}{c}\text { Introduction to } \\
\text { profession }\end{array}$ & The legal framework of inclusive education in general education institutions \\
\hline Psychology & Categories of children with special needs \\
\hline Pedagogy & Patterns and principles of inclusive education \\
\cline { 2 - 3 } & Forms and methods of teaching children with special needs \\
\cline { 2 - 3 } & The interaction between teachers and parents in the context of inclusive education \\
\hline $\begin{array}{c}\text { Teaching } \\
\text { methodology }\end{array}$ & Methods of inclusive education \\
\cline { 2 - 3 } & Support of the educational process in inclusive classes \\
\cline { 2 - 3 } & Correction and development work with children with special needs \\
\cline { 2 - 3 } & Characteristics and toolset for assessing children with special needs \\
\hline $\begin{array}{c}\text { Theory and } \\
\text { methods of } \\
\text { character building }\end{array}$ & Forms and methods of character building for children with special needs \\
\end{tabular}

Tab. 1. Topics added to professional courses for future handicraft teachers (bachelor's degree).

It is also important that future teachers can effectively implement methods of inclusive education. Thus, they should be able to organize practical activities of pupils, choose the most optimal forms and methods of working with different categories of children with special needs, cooperate with their parents intending to increase the efficiency of the educational process and enhance the quality of handicraft lessons. Such courses as Teaching Methodology, Learning Theories and teacher placements can mainly develop the professional skills of future teachers. The leading role in this process is played by the lecturers, who conduct professional training of the specialists mentioned above, and the teachers, who supervise teacher placements. However, the results obtained from self-analysis show that only $5.26 \%$ of teachers consider themselves ready to work in inclusive classes, whereas $19.3 \%$ are partially ready, and $75.44 \%$ are not ready at all. Respondents explain their answers as follows: the lack of knowledge of inclusive education $(43.86 \%)$; the insufficient knowledge of inclusive education methods (33.33\%); emotional imperception of activities in inclusive classes (22.81\%). Given an inadequate level of handicraft teachers' readiness for inclusive education, one can relate it to improper training of students for inclusive education during teacher placements. This is confirmed by the results obtained from the survey of students about the readiness to work in inclusive classes (see Fig. 3).

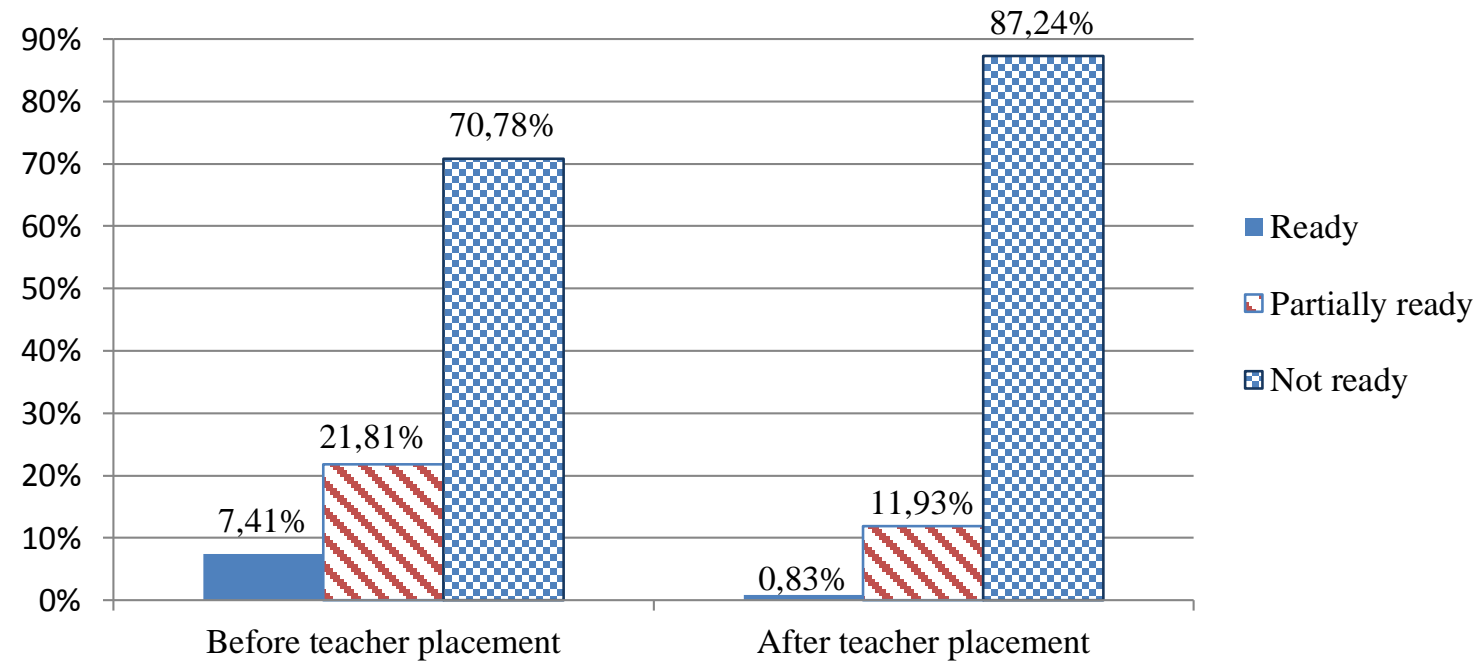

Fig. 3. Students' readiness to work with inclusive classes before and after teacher placement. 
As evidenced by the analysis on the results obtained from the survey of students majoring in secondary education (handicraft and technology) and secondary education (physical education), their views on the readiness to work in inclusive classes differ significantly before and after the teacher placement. Before the teacher placement, $7.41 \%$ of students considered themselves ready to work with children with special needs, whereas their number decreased to $0.83 \%$ after teacher placement. Before teacher placement, $21.81 \%$ of future handicraft teachers expressed partial willingness to work in inclusive classes. After teacher placement, their number decreased to $11.93 \%$. The number of students who are not ready to work with inclusive classes is disturbing as well: $70.78 \%$ - before the teacher placement, $87.24 \%$ - after teacher placement.

It must be noted that this problem concerns not only higher education institutions but also general education institutions and out-of-school education institutions, where inclusive classes are being actively introduced, and teachers are not ready to work in them. According to the Ministry of Education and Science of Ukraine (2017), "1825 positions for teacher assistants were introduced in general education institutions in 2016/2017 (in comparison, only 994 positions in 2015-2016) to assist children with special needs in acquiring educational material". However, most of them have not obtained adequate training, which complicates the implementation of the educational process. Therefore, it is expedient to conduct compulsory courses for improving teacher qualifications aimed at promoting readiness for working in inclusive classes. The preliminary topic draft for advanced training courses for handicraft teachers is presented in Table 2.

\begin{tabular}{|c|c|c|c|}
\hline \multirow[b]{2}{*}{ No } & \multirow[b]{2}{*}{ Topic } & \multicolumn{2}{|c|}{ Hours } \\
\hline & & Lectures & $\begin{array}{c}\text { Practical } \\
\text { classes }\end{array}$ \\
\hline \multicolumn{4}{|c|}{ Module 1. Theoretical principles of inclusive education } \\
\hline 1. & $\begin{array}{l}\text { The core of inclusive education. Legal documents on inclusive education. } \\
\text { Practical work 1. Analysing legal documents on inclusive education. }\end{array}$ & 2 & 2 \\
\hline 2. & $\begin{array}{l}\text { Categories of children with special needs, their psychological characteristics. } \\
\text { Practical work } 2 \text {. Identifying categories of children with special needs and their } \\
\text { characteristics. }\end{array}$ & 2 & 2 \\
\hline 3. & $\begin{array}{l}\text { Inclusive educational environment: the essence, implementation conditions } \\
\text { and requirements. } \\
\text { Practical work } 3 \text {. Determining the conditions for creating and implementing a } \\
\text { productive, inclusive educational environment. }\end{array}$ & 2 & 2 \\
\hline 4. & $\begin{array}{l}\text { Interaction between educational institution and parents of children with } \\
\text { special needs } \\
\text { Practical work } 4 \text { (training session). The characteristics of interaction with } \\
\text { parents of children with special needs. }\end{array}$ & 2 & 2 \\
\hline 5. & $\begin{array}{l}\text { Establishing interpersonal relations between pupils in inclusive classes. } \\
\text { Practical work } 5 \text { (training session). Interaction in inclusive classes. }\end{array}$ & 2 & 2 \\
\hline 6. & $\begin{array}{l}\text { Qualification requirements for teacher assistants and teachers working in } \\
\text { inclusive classes. } \\
\text { Practical work } 6 \text {. Designing a Professio Gramma of the handicraft teacher } \\
\text { working in inclusive classes. }\end{array}$ & 2 & 2 \\
\hline \multicolumn{4}{|c|}{ Module 2. Methodical principles of inclusion in the educational process } \\
\hline 7. & $\begin{array}{l}\text { Characteristics of forms and methods for teaching children with special } \\
\text { needs. } \\
\text { Practical work } 7 \text {. Choosing effective forms and methods for teaching children } \\
\text { with special needs. }\end{array}$ & 2 & 2 \\
\hline 8. & $\begin{array}{l}\text { Methodical support of education for children. } \\
\text { Practical work } 8 \text {. Elaborating methodical support of the education of children } \\
\text { with special needs. }\end{array}$ & 2 & 2 \\
\hline 9. & Psychopedagogical characteristics of identifying the level of educational & 2 & 2 \\
\hline
\end{tabular}




\begin{tabular}{|l|l|l|l|}
\hline & $\begin{array}{l}\text { attainment in children with special needs. } \\
\text { Practical work 9. Developing criteria for identifying the level of educational } \\
\text { attainment in children with special needs. }\end{array}$ & Inclusive classes. \\
\hline 10 & $\begin{array}{l}\text { Implementing differentiated approach in inclusical work 10. Compiling lesson notes for inclusive classes. } \\
\text { Practical }\end{array}$ & 2 & 2 \\
\hline
\end{tabular}

Tab. 2. Topics of lectures and practical classes for advanced training of handicraft teachers in the context of inclusive education.

The results of the advanced teacher training, which aims to develop readiness for pedagogical activity under the conditions of inclusion based on the proposed thematical plan help to identify the level of readiness in handicraft teachers for pedagogical activity in inclusive classes. They indicate some positive dynamics (see Fig. 4).

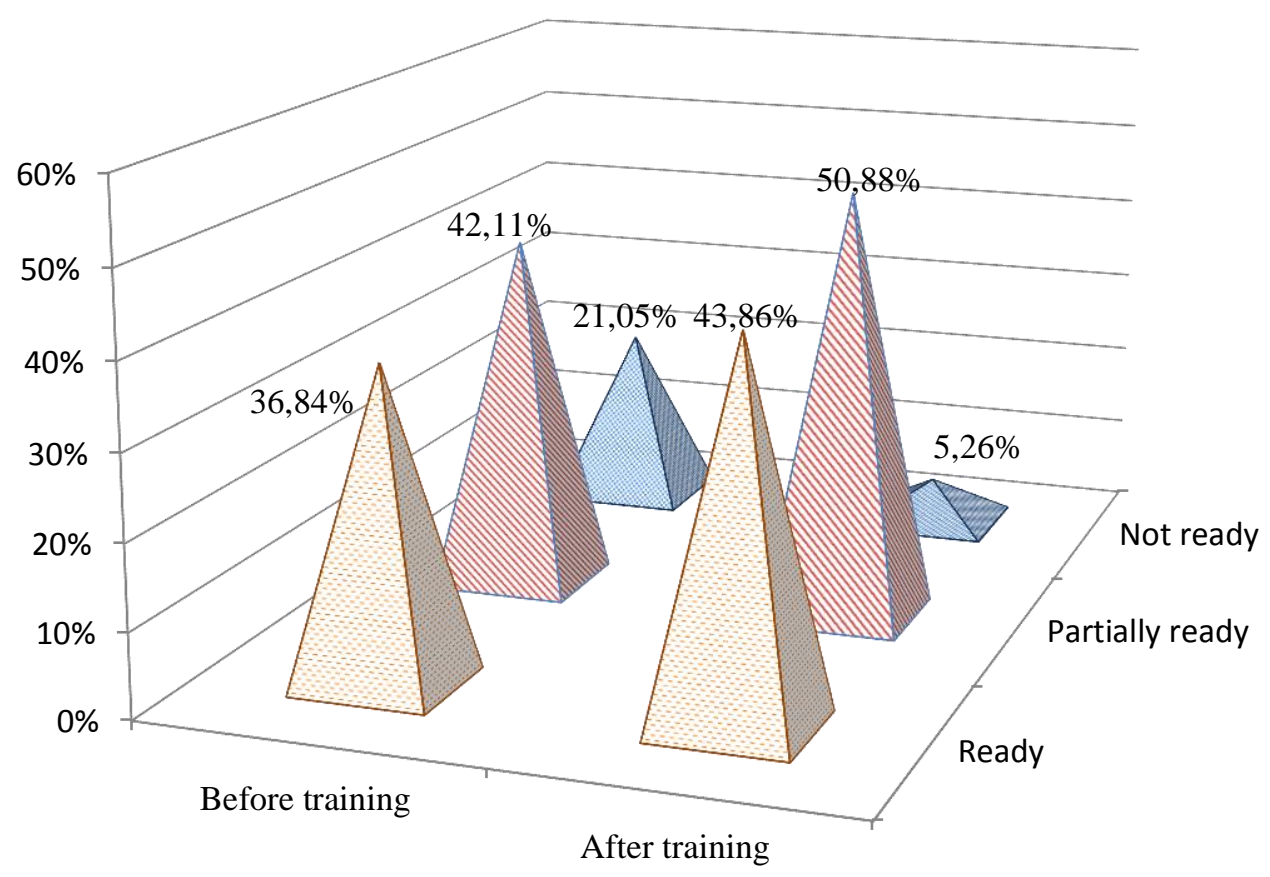

Fig. 4. Teachers' readiness to work with inclusive classes before and after the advanced teacher training.

At the same time, practising teachers point out to the following challenges of organizing the educational process in inclusive classes: many pupils (up to 30), which makes it impossible to carry out educational tasks; lack of specialized educational and methodical materials for various subjects, including handicrafts; lack of necessary facilities and equipment in gyms and workshops for students with special needs.

The research results prove that only $10.53 \%$ of teachers have a positive attitude towards the introduction of inclusive education; $33.33 \%$ - a mostly positive attitude; $7.02 \%$ - a negative attitude; $29.82 \%$ - a mostly negative attitude.

Therefore, it is of priority to pay considerable attention to the psychological readiness of teachers to work with children with special needs. To this end, it is of primary importance to approve the applicants who arable to work in the "man-man" system already at the stage of career guidance. Secondly, it is essential to hold training sessions, business games simulating pedagogical situations with children with special needs during professional training in higher education institutions so that future teachers can develop behavioural algorithms in most typical situations.

The analysis of the results obtained from the survey and the study of handicraft teachers' work experience makes it possible to discover the novel ways to enhance professional training of the specialists mentioned above in terms of inclusive education:

- to increase the psychological readiness of students to work with children with special needs; 
- to incorporate the principles of inclusive education into professional courses for future handicraft teachers;

- to teach students to implement methods of inclusive education in handicraft lessons.

In higher education institutions, these objectives are realized through the introduction of relevant topics and subjects. However, not all educators are aware of the importance and complexity of such training. The proposed lectures and practical classes on the implementation of inclusive education for handicraft teachers have proved to be effective. Indeed, the teachers note that they have improved their confidence to work with inclusive classes and consolidated their knowledge about the methods of working with children with special needs. It, in turn, has increased their readiness to implement inclusive education.

It must be noted that the effective implementation of the educational process in inclusive classes largely depends on both promotions of knowledge and skills in inclusive education and teachers' personality traits, such as empathy, reflection, humanism, kindness, compassion, communicability.

\section{CONCLUSIONS}

Thus, the analysis of the results obtained from the survey of handicraft teachers and, accordingly, students majoring in these areas shows that they are not ready to implement inclusive education in general education institutions. This requires that the content of these specialists' professional training should be updated. Besides, advanced training courses, methodological seminars and roundtables for handicraft teachers should be regularly held. This will increase their readiness to implement inclusive education and allow them to adjust to children with special needs.

\section{REFERENCES}

[1] Baranauskiene I. The right of people with disabilities to health: what is expressed by the architectonics of legislation? Social welfare: interdisciplinary approach, 2 (8) (2018), 40-52. doi.org/10.21277/sw.v2i8.402.

[2] Diatlenko N.M. The course "Professional Activities of Teacher Assistants in an Inclusive Classroom": the programme and methodical support are ready to go. Education Management: A Journal for Education Administrators, 337 (2014), 5-7. (in Ukrainian)

[3] The Bologna process revisited: the future of the European higher education area. Yerevan Communiqué of the European Ministers of Education of 14-15 May 2015. EHEA, 2015. Available at: http://www.ehea.info/media.ehea.info/file/2015_Yerevan/71/1/Bologna_Process_Revisited_Future_of_th e_EHEA_Final_613711.pdf.

[4] Korniienko D. Inclusive education in Ukraine: “Those, who build and those, who destroy ..." Gazeta.ua, February 2 (2018). Available at: https://gazeta.ua/articles/life/_inklyuzivna-osvita-v-ukrayini-tojmuruye-toj-rujnuye/818388. (in Ukrainian)

[5] Leonova M. 8212 inclusive classes to be opened in Ukrainian schools in 2018. Hromadske, August 21 (2018). Available at: https://hromadske.ua/posts/u-2018-rotsi-v-ukraini-vidkryiut-8212-inkliuzyvnykhklasiv-prezydent. (in Ukrainian)

[6] Levchenko L.S. Developing inclusive education in Ukraine. Pedagogical Sciences: Theory, History, Innovative Technologies, 3 (47) (2015), 27-36. (in Ukrainian)

[7] Loreman T., Deppeler J.M., Harvey D.H.P. Inclusive education: a practical guide to supporting diversity in the classroom. Allen \& Unwin, Sydney, 2005. doi.org/10.1017/s1030011200025252

[8] Statistical data. Ministry of Education and Science of Ukraine, 2017. Available at: https://mon.gov.ua/ua/statistichni-dani. (in Ukrainian)

[9] On Approval of Arrangement Procedure of Inclusive Education in Secondary Schools, 872 (2011). (in Ukrainian) 
[10] On Approval of the Concept of Inclusive Education Development, 912 (2010). (in Ukrainian)

[11] On Education, 2145-VIII (2017). Available at: http://zakon.rada.gov.ua/laws/show/2145-19. (in Ukrainian)

[12] On Ratification of the Convention on the Rights of Persons with Disabilities and Optional Protocol to It, 1767VII (2010). (in Ukrainian)

[13] Polloway E.A., Patton J.R., Smith, J.D., Smith T.E.C. Historical changes in mental retardation and developmental disabilities. Education \& Training in Mental Retardation and Developmental Disabilities, 31 (1) (1996), 3-12. Available at: https://www.jstor.org/stable/23879018.

[14] Porter G. Disability and inclusive education, 2001.

[15] The All-Ukrainian Foundation "Step by Step". Available at: http://www.ussf.kiev.ua/. (in Ukrainian/ in English)

[16] UN Convention on the Rights of the Child. Unicef, 1989. Available at: https://www.unicef.org/ukraine/ukr/convention_small_final.pdf. (in Ukrainian)

Address: Iryna Androshchuk, Ihor Androshchuk, Hanna Krasylnykova, Khmelnytskyi National University, 11 Instytutska St., Khmelnytskyj 29016, Ukraine.

E-mail: ivandroshchuk@ukr.net; lemen77@ukr.net; krasil@ukr.net.

Received: 10.01.2021; revised: 18.02.2021.

Андрощук Ірина, Андрощук Ігор, Красильникова Ганна. Підготовка майбутніх вчителів трудового навчання до реалізації інклюзивної освіти в українських школах. Журнал Прикарпатського університету імені Василя Стефаника, 8 (1) (2021), 122-131.

У статті висвітлено результати емпіричного дослідження щодо виявлення проблем реалізації інклюзивної освіти в контексті підготовки майбутніх учителів трудового навчання та визначення напрямів їх усунення. 3'ясовано, що майбутні вчителі трудового навчання у своїй переважній більшості не готові до реалізації інклюзивної освіти. Насамперед, це пов'язано з відсутністю у них на належному рівні сформованих знань і умінь щодо роботи 3 дітьми 3 особливими потребами. Виявлена необізнаність студентів щодо категорій дітей із вадами психофізичного розвитку та особливостей корекційно-розвивальної роботи з ними на уроках трудового навчання, під час яких учні активно залучені до виконання певних видів трудових вправ, активної рухової діядьності, що викликає у майбутніх педагогів занепокоєння та страх. Саме робота з різними інструментами під час обробки конструкційних матеріалів вимагає від педагога не дише організації безпечної праці, а й відповідної проектно-технологічної діяльності учнів на уроці. Встановлено, що керівники педагогічних практик, не маючи відповідного досвіду роботи 3 дітьми з особдивими потребами, не в змозі сформувати у студентів алгоритм дій з цією категорією учнів. Обгрунтована необхідність формування у студентів психологічної готовності до роботи з дітьми із особливостями психофізичного розвитку; оновлення змісту дисциплін професійної підготовки майбутніх учителів трудового навчання 3 врахуванням особливостей інклюзивного навчання; формування здатності до реалізації методик інклюзивного навчання та виховання на уроках трудового навчання. Виокремлено основні напрями, що сприятимуть підвищенню ефективності професійної підготовки майбутніх учителів трудового навчання у закладах вищої освіти до роботи з дітьми із особливостями психофізичного розвитку. потребами.

Кдючові слова: вчителі трудового навчання, інкдюзивна освіта, діти 3 особливими 